\title{
Importance of within-shoot epiphyte distribution for the carbon budget of seagrasses: the example of Posidonia oceanica
}

\author{
Teresa Alcoverro ${ }^{1, *}$, Marta Pérez ${ }^{2}$ and Javier \\ Romero² \\ ${ }^{1}$ Centre d'Estudis Avançats de Blanes, CSIC, C/ACC \\ Cala St. Francesc, 14, 17300 Blanes, Girona, Spain, \\ e-mail: teresa@ceab.csic.es \\ 2 Departament d'Ecologia, Universitat de Barcelona, \\ Avgda. Diagonal 645, 08028 Barcelona, Spain \\ ${ }^{*}$ Corresponding author
}

\begin{abstract}
To assess the effects of shading by epiphytes on the carbon balance of the seagrass Posidonia oceanica, we examined the patterns of within-shoot epiphyte abundance on leaves, and their variability with season and depth. Epiphyte biomass was found to depend on leaf age (larger epiphyte load on older tissues), leaf side (more epiphytes on the inner face than on the outer) and depth (more epiphytes in deep meadows). Depth differences were maximum in spring and disappeared in late summer. Percent light absorbed (absorptance) by epiphytes was measured; light absorptance followed an exponential-saturated model with epiphyte biomass. Combining these data of percent light absorbed, within-shoot epiphyte biomass distribution and an existing carbon balance model, we conclude that reduction in carbon gains caused by epiphyte shading is relatively small, and greater in deep meadows $(8.8 \%$ on average, with values up to $14.2 \%$ in May) than that in shallow water $(4.7 \%$ on average with maximum values of $7 \%$ in August). This is mainly due to the accumulation of epiphytes on old tissues, which contribute only marginally to the carbon gain of the plant. Using the same procedure, we modelled the effects of a doubling in epiphyte biomass, conserving the observed within-shoot distribution. The result was a very small additional carbon loss. However, using the same biomass but modifying the distribution (shifting the same abundance towards younger leaf age classes), the reduction in carbon gains was dramatic, particularly in deep meadows (between $21 \%$ and $41 \%$, depending on the shift used). Therefore, it is the epiphyte growth timing rate rather than the final biomass reached which seems to be a key control for Posidonia oceanica survival, especially near the deep limit of its distribution.
\end{abstract}

Keywords: carbon balance; irradiance; Mediterranean Sea; photosynthesis; seagrass.

\section{Introduction}

Light is generally considered to be the primary environmental factor controlling photosynthesis, growth and depth distribution of seagrasses (Bulthuis 1983, Dennison 1987, Duarte 1991). Light availability for seagrass leaves is dependent on abiotic factors such as weather conditions, sun-angle, sea surface roughness and water transparency, among others (Zimmerman et al. 1994, Dunton 1994, Herzka and Dunton 1998), as well as on factors related to biotic interactions, among which selfshading and epiphyte overgrowth are the most relevant (Bulthuis and Woelkerling 1981, Pérez and Romero 1992, Dalla Via et al. 1998). Although other aspects of plantepiphyte interaction should not be discarded (e.g., interference in gas exchange, Sand-Jensen et al. 1985, or nutrient uptake, McRoy and Goering 1974), the main effect of epiphytes on the seagrass is to decrease the light reaching the leaf surface. Epiphyte colonisation alters the light microenvironment through shading, thereby notably reducing light availability to the leaf surface (Sand-Jensen 1977, Sand-Jensen et al. 1985, Drake et al. 2003). This effect has potentially relevant implications for photosynthesis and carbon gain and, therefore, for plant survival. Light reductions of up to $30-50 \%$ of the incident radiation caused by epiphytes on old leaves have been observed in some seagrasses (Zostera marina L.: Sand-Jensen 1977, Mazzella and Alberte 1986, Drake et al. 2003; Heterozostera tasmanica [Martens ex Aschers.] den Hartog: Bulthuis and Woelkerling 1983). Under certain conditions (e.g., eutrophication), epiphyte cover may seriously affect plant vitality and cause seagrass decline (Orth and Moore 1983, Cambridge and McComb 1984).

Posidonia oceanica (L.) Delile is the dominant seagrass in the Mediterranean sublittoral zone and it is distributed across a wide bathymetric range, from near the surface down to $15-45 \mathrm{~m}$, depending on water turbidity. The long life span of $P$. oceanica leaves (more than 200 days, Romero 1989a) allows the development of a dense epiphytic community (Buia et al. 1989), which can contribute up to $40 \%$ to the total biomass of $P$. oceanica canopies (Mazzella and Ott 1984, Romero 1989b). This seagrass seems to be currently undergoing a significant decline in some areas of the northwestern Mediterranean Sea (Marbà and Duarte 1996), which might be due, at least in part, to the increasing turbidity of coastal waters or to the increasing epiphyte loading, both resulting from anthropogenic eutrophication (Guidetti and Fabiano 2000, Pergent et al. 1999). The sensitivity of $P$. oceanica to light reduction is crucial in the summer months, since high light availability allows high photosynthetic rates, which lead to carbohydrate storage for overwintering (Alcoverro 
et al. 2001). During this period (late spring-summer), epiphyte cover on $P$. oceanica leaves reaches maximum values. This is caused by the interplay of several factors, including those related to the seasonal cycle of leaf growth, the solar cycle and consumption by herbivores (Casola et al. 1987, Romero 1989b, Alcoverro et al. 1997). However, the extent to which epiphytes interfere with carbon gain has been addressed only recently in a single seagrass species (Thalassia testudinum Banks ex König: Drake et al. 2003), whose leaves are relatively short-lived (Hemminga and Duarte 2000). Moreover, it is known that photosynthetic performances of leaves, and hence their relative contribution to carbon gains, are strongly dependent on leaf age, especially in species with long-lived leaves (Alcoverro et al. 1998). Therefore, we hypothesised that, in such species, the final effect of epiphytes on carbon gains through shading would be determined by within-shoot epiphyte distribution, and tested this hypothesis in $P$. oceanica. This hypothesis, as far as we are aware, had never been addressed previously.

In this study, the interaction between Posidonia oceanica and its epiphytes was examined. In particular, through the examination of the seasonal and depth patterns of within-shoot epiphyte distribution, and through the evaluation of the shading effects of epiphytes and the resulting consequences on plant carbon gains we looked at the way in which shading by epiphytes interferes with carbon acquisition by the host plant.

\section{Materials and methods}

The study site chosen was a Posidonia oceanica meadow in the Medes Islands, a locality with a high epiphyte biomass as a result of a nearby river discharge (Alcoverro et al. 1997). Sampling was performed at both a shallow $(5 \mathrm{~m})$ and a deeper site (13 $\mathrm{m}$, close to the deep seagrass limit at this site, Alcoverro et al. 1995) and at three periods during 2000 , which included, in principle, the onset of epiphyte biomass increase (March), maximum epiphyte biomass (end of May) and epiphyte biomass decrease (end of August). At each sampling event and site, ten $P$. oceanica shoots were collected by SCUBA divers and rinsed with running seawater. Five shoots were sorted into leaf segments, corresponding to four age classes (in days): 0-25 (A1), 25-50 (A2), 50-100 (A3) and 100-150 (A4), following the methodology described elsewhere (Alcoverro et al. 1998). The length and width of each leaf class was measured, and epiphytes growing on the external side (facing the periphery of the leaf bundle) and internal side (facing the centre of the leaf bundle; see Dalla Via et al. 1998) were removed separately by scraping the surface with a razor blade. Leaves and epiphytes were weighed after desiccation $\left(70^{\circ} \mathrm{C}\right.$ to constant weight). Shading by epiphytes on $P$. oceanica leaves was assessed with the remaining shoots for each sampling event; to this end, leaf portions ( $8 \mathrm{~cm}$ in length) with distinct epiphyte biomass were chosen. Leaves were gently patted with a tissue to remove water immediately before being placed in a dual beam scanning spectrophotometer. Measurements of leaf transmittance at $1 \mathrm{~nm}$ inter- vals between 400 and $700 \mathrm{~nm}$ (see Alcoverro et al. 1997, Cebrián et al. 1999 for details) were taken for each leaf portion before and after gently scraping away the epiphytes with a razor blade (Drake et al. 2003). Each measurement was taken five times to account for epiphyte patchiness within each leaf. To evaluate extinction caused by epiphytes, transmittances at 430 , at $665 \mathrm{~nm}$ and integrated transmittance between 400 and $700 \mathrm{~nm}$ were recorded.

Light absorption was expressed as absorptance (i.e., the fractional light absorbed by pigments), which was derived from absorbance (i.e., optical density, which reflects the logarithmic light absorption) using the following equation (Clayton 1973):

\section{Percent light absorbed $=\left(1-10^{- \text {absorbance }}\right) \times 100$}

Percent light shading by epiphytes was estimated as the difference between the fraction absorbed before and after epiphyte removal. Epiphytes and leaf portions were then weighed after desiccation $\left(70^{\circ} \mathrm{C}\right.$ to constant weight).

To check whether not taking into account the reflectance of leaves and epiphytes could bias our results, we compared our data with those obtained by Drake et al. (2003) who used an integrating sphere. We transformed epiphyte dry weight to carbon units (average carbon content in the epiphytes $=20 \%$, see Alcoverro et al. 1997). Our results showed a strong linear relationship with those obtained using the integrating sphere $\left(r^{2}=0.93\right.$ for $430 \mathrm{~nm}$ and $\mathrm{r}^{2}=0.95$ for $665 \mathrm{~nm}$ ). The line had a zero intercept (t-test for differences from $y$-intercept $=0$ : $\mathrm{p}=0.37$ and $\mathrm{p}=0.22$ for $430 \mathrm{~nm}$ and $665 \mathrm{~nm}$ respectively), but the slope was slightly different from 1.0 (slope $=0.94 \pm 0.09$ and $0.88 \pm 0.07$ for $430 \mathrm{~nm}$ and $665 \mathrm{~nm}$, respectively, probability of error in rejecting the null hypothesis of slope $=1.0, p<0.0001$ in both cases). This indicates a slight underestimate of light absorptance by epiphytes (6-12\% for the PAR spectrum) in this work; however, we consider that results are fully representative of the magnitude of the shading effect.

Differences in epiphyte biomass distribution between tissue age (4 levels), leaf side ( 2 levels), month (3 levels) and depth (2 levels) were assessed with a four-way ANOVA with the four fixed variables (Underwood 1997). Data were log-transformed to homogenise variances (after Cochran's C-test). When appropriate, Student NewmanKeuls (SNK) tests were used for a posteriori comparisons of the means.

\section{Results}

Epiphyte load was always higher in the oldest leaves and this effect was maximum in the deep meadows in May (see significant interaction between depth $\times$ tissue age $\times$ sampling time, Table 1, Figure 1). Epiphytes were more abundant on the internal than on the external side of the leaves (Figure 2, Table 1), and these differences were especially great in the most loaded leaves (i.e., the oldest, see significant interaction between tissue age and leaf side, Table 1), and in May (significant interaction between sampling time and leaf side, Table 1). 
Table 1 Posidonia oceanica: analysis of variance of epiphyte biomass ( $\mathrm{mg} \mathrm{cm}^{-2}$ ) by sampling time (April, May and August), depth (shallow and deep meadow), tissue age (A1, A2, A3, A4) and leaf side (external or internal). ${ }^{\text {a }}$

\begin{tabular}{|c|c|c|c|c|c|}
\hline Variable & Source & df & MS & $\mathrm{F}$ & $p$ \\
\hline Epiphyte biomass & Month (M) & 2 & 0.60 & 23.12 & *** \\
\hline \multirow[t]{15}{*}{ (mg cm ${ }^{-2}$ shoot) } & Depth (D) & 1 & 0.34 & 13.4 & 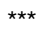 \\
\hline & Tissue age (T) & 3 & 8.75 & 335.9 & *** \\
\hline & Leaf side (S) & 1 & 0.50 & 19.44 & $\star \star$ \\
\hline & $M^{\star} \mathrm{D}$ & 2 & 0.49 & 18.82 & 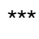 \\
\hline & $M^{\star} T$ & 6 & 0.19 & 7.48 & *** \\
\hline & $\mathrm{D} * \mathrm{~T}$ & 3 & 0.61 & 23.64 & *** \\
\hline & $M^{\star} S$ & 2 & 0.11 & 4.38 & $\#$ \\
\hline & $D^{\star} S$ & 1 & 0.05 & 2.30 & ns \\
\hline & $T^{\star} S$ & 3 & 0.14 & 5.69 & *** \\
\hline & $M * D^{\star} T$ & 6 & 0.26 & 10.11 & 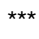 \\
\hline & $M^{\star} D^{\star} S$ & 2 & 0.03 & 1.17 & ns \\
\hline & $M^{\star} T^{\star} S$ & 6 & 0.04 & 1.70 & ns \\
\hline & $D^{\star} T^{\star} S$ & 3 & 0.02 & 0.93 & ns \\
\hline & $M^{\star} D^{\star} T^{\star} S$ & 6 & 0.01 & 0.46 & ns \\
\hline & Error & 192 & 0.02 & & \\
\hline
\end{tabular}

a Results were assessed with a four-way ANOVA (4 fixed variables). ns, not significant at $p>0.05 ;{ }^{*} p<0.05 ;{ }^{\star \star} p<0.01,{ }^{\star \star \star} p<0.001$; data log +1 transformed; Cochran's Test $\mathrm{C}=0.087, \mathrm{p}>0.05$

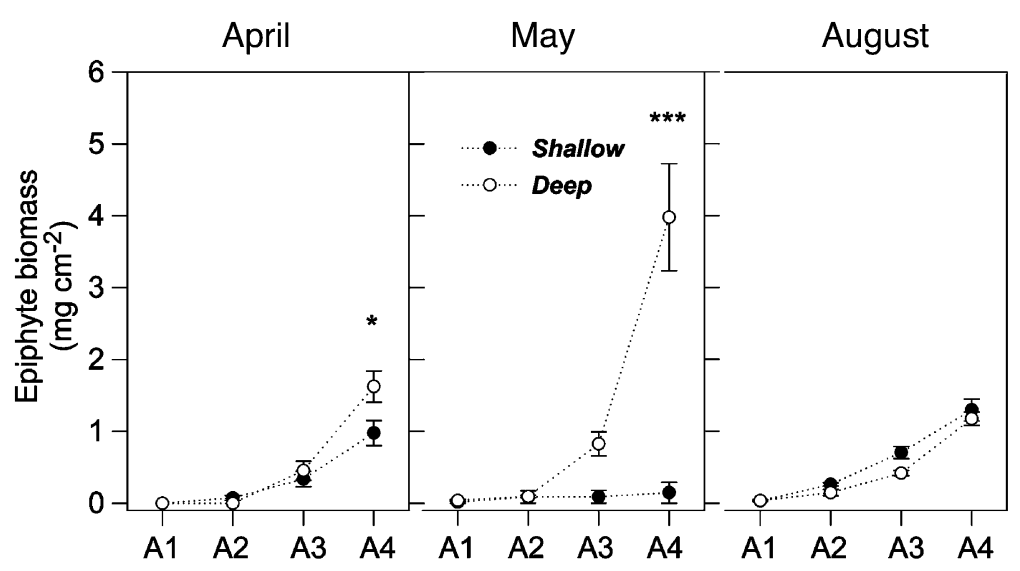

Figure 1 Posidonia oceanica: distribution of the epiphyte biomasss (average of the two leaf sides) by tissue age for April, May and August in shallow and deep meadows.

A1 corresponds to the youngest tissue, while A4 corresponds to the oldest. Points and bars represent the mean and standard error $(n=5)$. SNK test for paired comparisons at $p>0.05$; ${ }^{*} p<0.05$; ${ }^{\star \star *} p<0.001$.

Absorptance by epiphytes increased with epiphyte biomass following an exponential saturation function (Figure 3). After an initial rapid increment, light absorptance by epiphytes reached, in all cases, a maximum val-

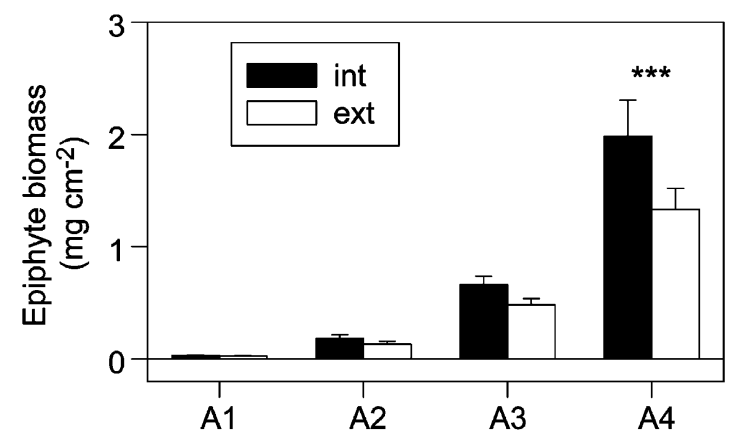

Figure 2 Posidonia oceanica: distribution of the epiphyte biomass (average of the three sampling times and two depths) by tissue age and leaf side (external and internal).

A1 corresponds to the youngest tissue, while A4 corresponds to the oldest. Points and bars represent the mean and standard error $(n=6)$. SNK test for paired comparisons at $p>0.05$; *** $p<0.001$. ue of about $80 \%$ of incident light at biomasses higher than $3 \mathrm{mg} \mathrm{dw} \mathrm{cm}^{-2}$. This behaviour was well described by the following equations (Jassby and Platt 1976):

$$
\begin{aligned}
& A(430)=96.5[1-\exp (-\mathrm{B} / 1.95)] \\
& A(665)=86.1[1-\exp (-\mathrm{B} / 2.03)] \\
& A(400-700)=86.3[1-\exp (-\mathrm{B} / 2.11)]
\end{aligned}
$$

where $A$ represents the absorptance at the wavelengths indicated and $B$ represents epiphyte biomass ( $\mathrm{mg} \mathrm{dw} \mathrm{cm}^{-2}$ ). No differences among curves obtained for 430,665 and the range $400-700$ can be detected.

\section{Discussion}

Epiphyte accretion is a cumulative process, as shown by the relation between leaf age and the epiphytes present, thus leading to a great variability in within-shoot epiphyte biomass distribution, particularly in species with long- 
lived leaves such as Posidonia oceanica (Wittmann et al. 1981, Romero 1989a, Cebrián et al. 1994). Additional variability in within-shoot epiphyte biomass distribution is caused by the apparent preference of epiphytes for the internal side of the leaves. This finding, already reported in previous works (Dalla Via et al. 1998), is probably the result either of particular species preference for this sheltered side, or of a higher probability of settling of propagules there.

Season, and particularly, the interaction between season and depth (i.e., different seasonality between deep and shallow meadows) has also been demonstrated as an important factor in controlling epiphyte biomass accretion (Mazzella and Ott 1984, Ballesteros 1987). The significant difference in epiphyte biomass at 5 and $13 \mathrm{~m}$ depths during May (Figure 1) suggests that either epiphyte species composition differed between depths, or that conditions at $13 \mathrm{~m}$ were more favourable to epiphyte growth. In fact, differences in epiphyte composition between shallow and deep Posidonia oceanica leaves in spring have already been pointed out, in this and nearby areas. Shallow meadows were characterised by phaeophycean species, such as Giraudia sphacelaroides Derbès et Solier, Cladosiphon irregularis (Sauvageau) Kylin, C. cylindricus (Sauvageau) Kylin, among others (Ballesteros et al. 1984, Ballesteros 1987), while in deep meadows zooepiphytes dominated (basically the hydrozoan Sertularia perpusilla (Stechow) and the bryozoans Electra posidoniae (Gautier) and Fenestrulina joannae (Calvet); Ballesteros et al. 1984, Ballesteros 1987).

To investigate the shading effect of epiphytes on the carbon balance of the plant, we combined the data of light absorption by epiphytes with an available carbon balance model (Alcoverro et al. 2001). This model takes into account seasonal changes in photosynthetic rates, as well as the different photosynthetic performances of the different leaf age classes. Thus, we computed net carbon gains for each leaf age-class (A1, A2, A3, A4), and for each leaf side (external or internal) at each depth ( $5 \mathrm{~m}$ and $13 \mathrm{~m}$ ) and season, first considering that all the light was reaching the leaf surface, and then introducing the shading effects by epiphytes. Light reduction caused by epiphytes for each leaf age, side (external or internal) and period was estimated from the non-linear relationship between the epiphyte biomass and the shading effect observed in this work (see Results). Following the results obtained by this method, it can be concluded that light absorption by epiphytes can decrease light availability reaching the leaf surface by up to $80 \%$ in old leaves; however, we estimate that total shoot carbon gains decrease only moderately. In the deep meadow, this decrease was, on average $8.8 \%$, relative to the estimated value obtained without epiphytes, with values up to $14.2 \%$ in May (Table 2). The reduction was even smaller in the shallow meadows $4.7 \%$ on average, with maximum values of $7 \%$ in August, Table 2). These observations can be explained by the fact that most epiphytes are concentrated in the oldest parts of the leaves, which only marginally contribute to the carbon gain by the seagrass (Alcoverro et al. 2001). While it is likely that this $5 \%$ reduction in carbon gains will be irrelevant for plants living in shallow waters, the $10 \%$ decrease near the deep
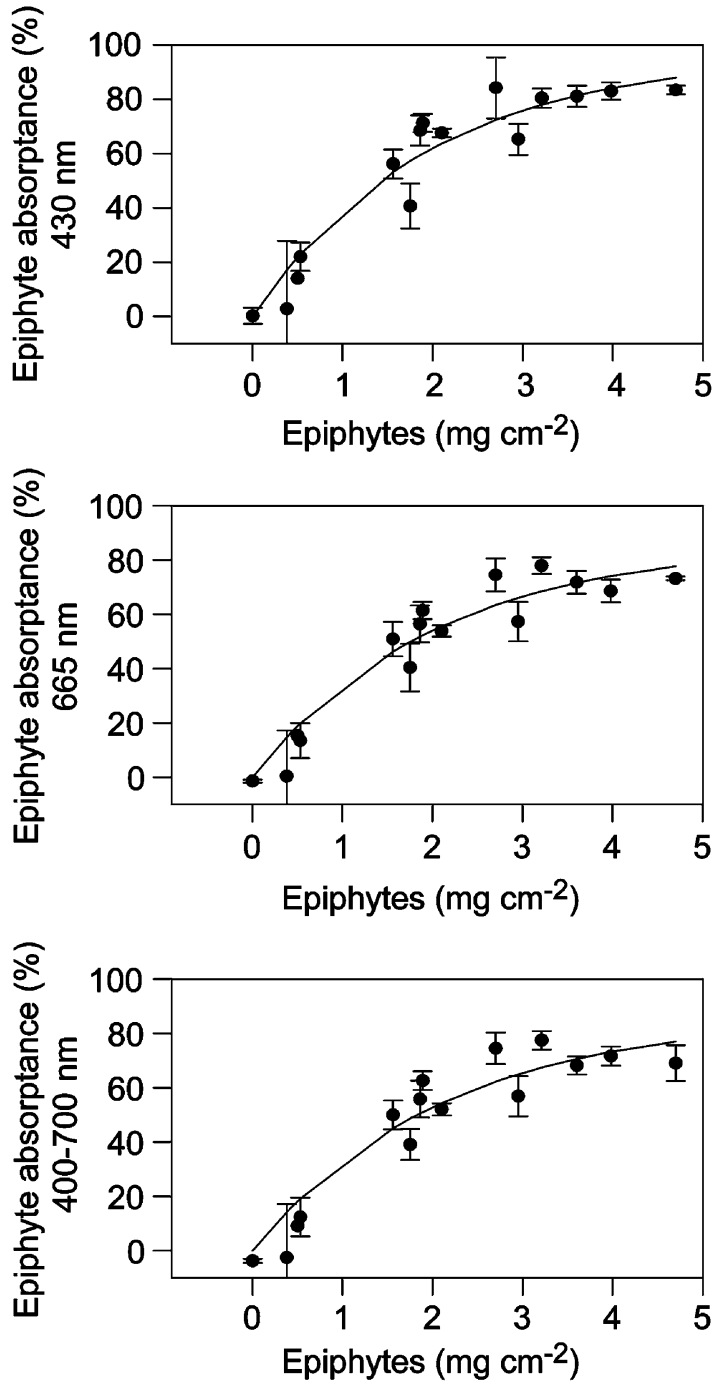

Figure 3 Posidonia oceanica: relationship between light absorptance by epiphytes and epiphyte biomass at wavelenghts of $665 \mathrm{~nm}, 430 \mathrm{~nm}$ and integrated between 400 and 700 .

Continuous lines represent the fitted exponential saturation curves (Jassby and Platt 1976, see text). Each measurement was taken five times to account for epiphyte patchiness within each leaf. Points and bars represent the mean and standard error $(n=5)$.

Table 2 Posidonia oceanica: monthly percent carbon reduction by the epiphytes shading at 5 and $13 \mathrm{~m}$ depths during the period studied.

\begin{tabular}{clc}
\hline Depth $(\mathrm{m})$ & Month & $\begin{array}{c}\text { \% Carbon reduction } \\
\text { by epiphytes }\end{array}$ \\
\hline \multirow{2}{*}{5} & April & 3.4 \\
& May & 4.4 \\
& June & 3.4 \\
& July & 6.5 \\
& August & 7.0 \\
& Average & 4.7 \\
& April & 9.3 \\
& May & 14.2 \\
& June & 8.8 \\
& July & 6.7 \\
& August & 6.9 \\
& Average & 8.8 \\
\hline
\end{tabular}



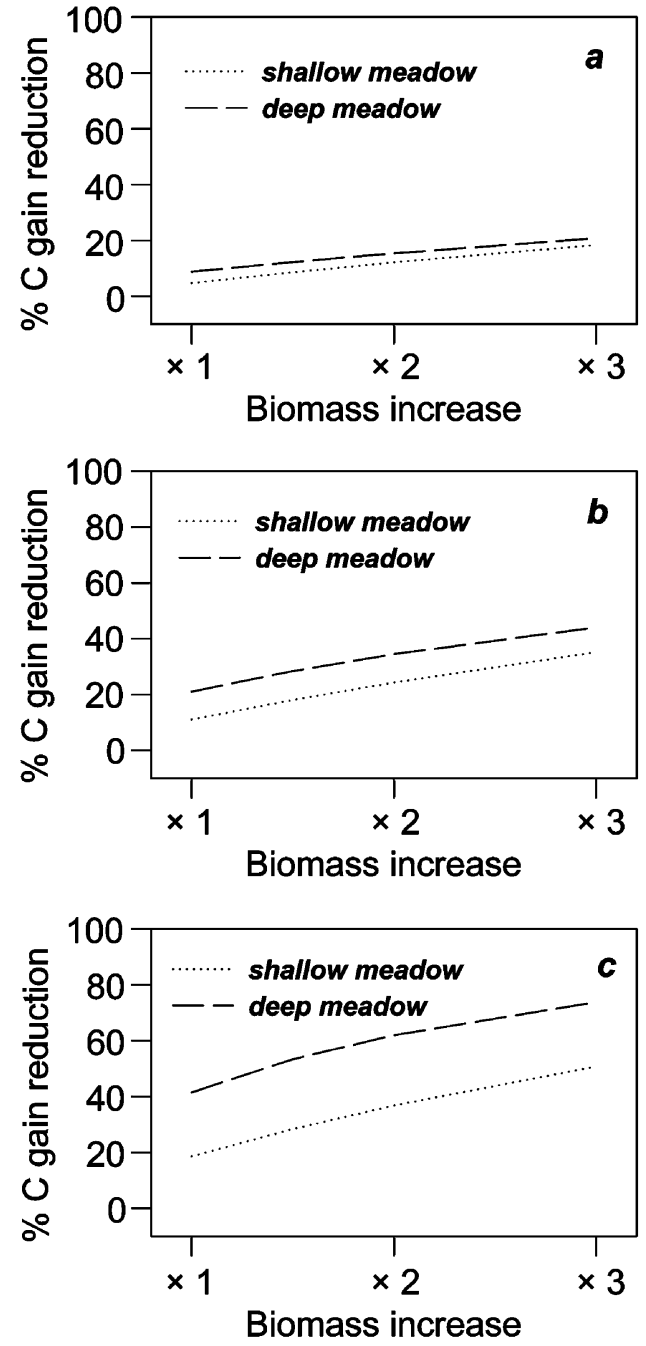

Figure 4 Posidonia oceanica: carbon gain reduction (\% relative to carbon gain without epiphytes) estimated when increasing between 1- and 3-fold the observed epiphyte biomass.

(a) without changes in the within-shoot biomass distribution, (b) shifting the biomass of epiphytes 50 days, (c) shifting the biomass of epiphytes 100 days.

limit of the plant distribution could be critical for plant survival and growth (e.g., Ruiz and Romero 2001). This suggests again that deeper seagrass meadows may be at more risk of deleterious effects of epiphyte loading if conditions alter. This is demonstrated when observing the percent of carbon loss among meadows and depths, confirming that May in deep meadows is also the month in which the major shading appears (14.2\%), while April is the month in which the epiphytes from shallow meadows have the least effect $(3.4 \%$ of carbon reduction, Table 2). The differences among these two depths were due not only to the higher epiphyte biomass in the deep meadow, but also to lower irradiance there and to the respective within-shoot biomass distribution.

To obtain an insight into the consequences of potential changes in (i) epiphyte load and (ii) within-shoot epiphyte distribution, we used the same procedure (data on epiphyte light absorption from this work combined with the carbon balance model). To simulate an increase in epiphyte biomass, we estimated the shading effects of biomass 1 to 3 times that measured in the field; to simulate changes in the within-shoot epiphyte distribution, we estimated the shading effects shifting the maximum epiphyte biomass to younger ages by 1 (50 days) and 2 (100 days) age classes. The results indicate that increases in epiphyte biomass (relative to that observed) did not result in clear decreases in carbon gains if the same within-shoot distribution was kept (Figure 4a). In contrast, when the biomass distribution of epiphytes was shifted towards younger age classes, the estimated carbon gains decreased by $20-70 \%$, depending on the shift and on the biomass (Figure $4 b, c)$.

Although some caution should be exercised with all of these estimates, especially because they do not include other possible interferences of epiphytes with leaf metabolism, it seems worthy of note that the effects of epiphytes on the seagrass would largely depend, at least in this species, on the time needed for propagules to settle and on the initial growth rates, rather than on the final epiphyte biomass reached. This aspect has to be considered in management plans for seagrass conservation, as well as for the use of epiphyte load as a biological indicator (Buzzelli et al. 2002).

We conclude that, even if epiphytes can substantially reduce light reaching leaves, especially in the old blades, the shading only moderately decreases the total shoot carbon gains. However, although moderate, this decrease in carbon acquisition at the deep limit of the plant distribution can be critical for survival, particularly if within-shoot distribution of epiphytes is modified. Traditionally, the deep limit of seagrass distribution has been attributed to the light attenuation coefficient of the water column (Duarte 1991). However, this deep limit, for a given water turbidity, can be modified by epiphyte biomass and particularly by the epiphyte within-shoot distribution.

\section{Acknowledgements}

We thank F. Tomàs and P. Renom for their help in the field work and $A$. Vergés for revising the manuscript text. Financial support was provided by a grant from CICYT (REN2002-04020).

\section{References}

Alcoverro, T., C.M. Duarte and J. Romero. 1997. The influence of herbivores on Posidonia oceanica epiphytes. Aquat. Bot. 56: 93-104.

Alcoverro, T., M. Manzanera and J. Romero. 1998. Seasonal and age-dependent variability of Posidonia oceanica (L.) Delile photosynthetic parameters. J. Exp. Mar. Biol. Ecol. 230: $1-13$.

Alcoverro, T., M. Manzanera and J. Romero. 2001. Annual metabolic carbon balance of the seagrass Posidonia oceanica: the importance of carbohydrate reserves. Mar. Ecol. Prog. Ser. 211: 105-116.

Ballesteros, E. 1987. Estructura I dinàmica del poblament algal de les fulles de Posidonia oceanica (L.) Delile als herbeis de Tossa de Mar (Girona). Bullt. Inst. Cat. Hist. Nat. Sec. Bot. 6: 13-30.

Ballesteros, E., Garcia, A., Lobo, A. and J. Romero. 1984. L'Alguer de Posidonia oceanica de les Illes Medes. In: (J.D. Ros, I. Olivella and J.M. Gili, eds) Sistemes naturals de les Illes Medes. Institut d'Estudis Catalans, Barcelona. pp. 739-756. 
Buia, M.C., M. Cormaci, G. Furnari and L. Mazzella. 1989. Posidonia oceanica off Capo Passaro (Sicily, Italy): leaf phenology and leaf algae epiphytic comunity. In: (C.F. Boudouresque, A. Meinesz, E. Fresi and V. Gravez, eds) International workshop on Posidonia beds. Vol. 2. GIS Posidonie, Marseille. pp. 127-143.

Bulthuis, D.A. 1983. Effects of in situ light reduction on density and growth of the seagrass Heterozostera tasmanica (Martens ex Aschers) den Hartog in Western Port, Victoria, Australia. J. Exp. Mar. Biol. Ecol. 61: 91-103.

Bulthuis, D.A. and W.J. Woelkerling. 1981. Effects of in situ nitrogen and phosphorus enrichment of the sediments on the seagrass Heterozostera tasmanica (Martens ex Aschers.) den Hartog in Western port, Victoria, Australia. J. Exp. Mar. Biol. Ecol. 53: 193-207.

Bulthuis, D.A. and W.J. Woelkerling. 1983. Biomass accumulation and shading effects of epiphytes on leaves of the seagrass, Heterozostera tasmanica, in Victoria, Australia. Aquat. Bot. 16: 137-148.

Buzzelli, C.P., R.L. Wetzel and M.B. Meyers. 2002. Dynamic simulation of littoral zone habitats in lower Chesapeake Bay. 2. Seagrass habitats primary production and water quality relationships. Estuaries 21: 673-689.

Cambridge, M.L. and J. McComb. 1984. The loss of seagrasses in Cockburn Sound, Western Australia. I. The time course and magnitude of seagrass decline in relation to industrial development. Aquat. Bot. 20: 229-234.

Casola, E., M. Scardi, L. Mazzella and E. Fresi. 1987. Structure of the epiphytic community of Posidonia oceanica leaves in a shallow meadow. PSZN: Mar. Ecol. 8: 285-296.

Cebrián, J., N. Marbà and C.M. Duarte. 1994. Estimating leaf age of the seagrass Posidonia oceanica (L.) Delile using the plastochrone interval index. Aquat. Bot. 49: 59-66.

Cebrián, J., S. Enríquez, M. Fortes, N. Agawin, J. Vermaat and C.M. Duarte. 1999. Epiphyte accrual on Posidonia oceanica (L.) Delile leaves: implications for light absorption. Bot. Mar. 42: $123-128$.

Clayton, R.K. 1973. Light and living matter. Vol. 1: the physical part. McGraw-Hill, New York. pp. 80.

Dalla Via, J., C. Sturmbauer, G. Schönweger, E. Sötz, S. Mathekowitsch, M. Stifter and R. Rieger. 1998. Light gradients and meadow structure in Posidonia oceanica: ecomorphological and functional correlates. Mar. Ecol. Prog. Ser. 163: 267-278.

Dennison, W.C. 1987. Effects of light on seagrass photosynthesis, growth and depth distribution. Aquat. Bot. 27: 15-26.

Drake, L.A., F.C. Dobbs and R.C. Zimmerman. 2003. Effects of epiphyte load on optical properties and photosynthetic potential of the seagrasses Thalassia testudinum Banks ex Köning and Zostera marina L. Limnol. Oceanogr. 48: 456-463.

Duarte, C.M. 1991. Seagrass depth limits. Aquat. Bot. 40: 363-377.

Dunton, K.H. 1994. Seasonal growth and biomass of the subtropical seagrass Halodule wrightii in relation to continuous measurements of underwater irradiance. Mar. Biol. 120: 479-489.

Guidetti, P. and M. Fabiano. 2000. The use of lepidochronology to assess the impact of terrigenous discharges on the primary leaf production of the Mediterranean seagrass Posidonia oceanica. Mar. Pol. Bull. 40: 449-453.

Hemminga, M.A. and C.M. Duarte. 2000. Seagrass ecology. Cambridge University Press, Cambridge. pp. 298.
Herzka, S.Z. and K.H. Dunton. 1998. Light and carbon balance in the seagrass Thalassia testudinum: evaluation of current production models. Mar. Biol. 132: 711-721.

Jassby, A.D. and T. Platt. 1976. Mathematical formulation of the relationship between photosynthesis and light for phytoplankton. Limnol. Oceanogr. 21: 540-547.

Marbà, N. and C.M. Duarte. 1996. Growth and population dynamics of Posidonia oceanica on the Spanish Mediterranean coast: elucidating seagrass decline. Mar. Ecol. Prog. Ser. 137: 203-213.

Mazzella, L. and R.S. Alberte. 1986. Light adaptation and the role of autotrophic epiphytes in primary production of the temperate seagrass, Zostera marina (L.). J. Exp. Mar. Biol. Ecol. 100: 165-180.

Mazzella, L. and J. Ott. 1984. Seasonal changes in some features of Posidonia oceanica (L.) Delile leaves and epiphytes at different depths. In: (C.F. Boudouresque, A. Jeudy de Grissac and J. Olivier, eds) International workshop on Posidonia beds. Vol 1. GIS Posidonie, Marseille. pp. 119-127.

McRoy, C.P. and J.J. Goering. 1974. Nutrient transfer between the seagrass Zostera marina and its epiphytes. Nature 248 : 173-174.

Orth, R.J. and K.A. Moore. 1983. Chesapeake Bay: an unprecedented decline in submerged aquatic vegetation. Science 222: 51-53.

Pérez, M. and J. Romero. 1992. Photosynthetic response to light and temperature of the seagrass Cymodocea nodosa and the prediction of its seasonality. Aquat. Bot. 43: 51-62.

Pergent, G., S. Mendez, C. Pergent-Martini and V. Pasqualini. 1999. Preliminary data on the impact of fish farming facilities on Posidonia oceanica meadows in the Mediterranean. Oceanologica Acta 22: 95-107.

Romero, J. 1989a. Seasonal pattern of Posidonia oceanica production: growth, age and renewal of leaves. In: (C.F. Boudouresque, A. Meinesz, E. Fresi and V. Gravez, eds) International workshop on Posidonia beds. Vol 2. GIS Posidonie, Marseille. pp. 63-68.

Romero, J. 1989b. Epífitos de las hojas de Posidonia oceanica: variaciones estacionales y batimétricas de biomasa en la pradera de las islas Medes (Girona). Oecologia aquatica 9: 19-25.

Ruiz, J.M. and J. Romero. 2001. Effects of in situ experimental shading on the Mediterranean seagrass Posidonia oceanica (I.) Delile. Mar. Ecol. Prog. Ser. 215: 107-120.

Sand-Jensen, K. 1977. Effect of epiphytes on eelgrass photosynthesis. Aquat. Bot. 3: 55-63.

Sand-Jensen, K, N.P. Revsbech and B.B. Jorgensen. 1985. Microprofiles of oxygen in epiphyte communities of submerged macrophytes. Mar. Biol. 89: 55-62.

Underwood, A.J. 1997. Experiments in ecology: their logic design and interpretation using analysis of variance. University Press, Cambridge. pp. 504.

Wittmann, K., L. Mazzella and E. Fresi. 1981. Age specific patterns of leaf growth: their determination and importance for epiphytic colonization in Posidonia oceanica (L.) Delile. Rapp. Com. Int. Mer. Médit. 27: 189-191.

Zimmerman, R., A. Cabello-Pasini and R.S. Alberte. 1994. Modelling daily production of aquatic macrophytes from irradiance measurements: a comparative analysis. Mar. Ecol. Prog. Ser. 114: 185-196.

Received 14 April, 2004; accepted 7 July, 2004 